\title{
THE RESURGENCE OF NATIONALISM: THE BREAKUP OF YUGOSLAVIA
}

\author{
Sergey Asaturov \\ Department of international relationship and social science \\ National University of bioresearches' and Environmental Sciences \\ 15 Heroiv Obobrony str., Kyiv, Ukraine, 03041 \\ asaturov555@ukr.net \\ Andrei Martynov \\ Department of international relation and foreign polity of Ukraine \\ Institute of History of Ukraine of National Academy of Science of Ukraine \\ 4 Hrushevskogo str., Kyiv, Ukraine, 01001 \\ martynov.andriy15@gmail.com
}

\begin{abstract}
The choice between modern nation-building and integration into supranational European and Euro-Atlantic structures remains a strategic challenge for the Balkan countries. Success in solving this problem of predominantly mono-ethnic Croatia and Slovenia has not yet become a model to follow. Serbian and Albanian national issues cannot be resolved. Serbia's defeat in the Balkan wars of 1991-1999 over the creation of a "Greater Serbia" led to the country's territorial fragmentation. Two Albanian national states emerged in the Balkans. Attempts to create a union of Kosovo and Albania could turn the region into a whirlpool of ultra-nationalist contradictions. The European Union has started accession negotiations with Albania, Bosnia and Herzegovina, the Republic of Northern Macedonia, Serbia and Montenegro. The success of these negotiations depends on the readiness of the EU and the ability of these Balkan states to adopt European norms and rules. The accession of all Balkan nation-states to the European Union must finally close the "Balkan window" of the vulnerability of the united Europe. Nation-building in the Balkans on the basis of ethnic nationalism sharply contradicts the purpose and current values of the European integration process. For more than three decades, the EU has been pursuing a policy of human rights, the rule of law, democracy and economic development in the Balkans. The region remains vulnerable to the influences of non-European geopolitical powers: the United States, Russia, Turkey, and China. The further scenario of the great Balkan geopolitical game mainly depends on the pro-European national consolidation of the Balkan peoples and the effectiveness of the European Union's strategy in the Balkans.
\end{abstract}

Keywords: Balkan, identity, cultural war, multicultural society, nationalism. Yugoslavia.

DOI: $10.21303 / 2504-5571.2020 .001440$

\section{Introduction}

Of all the explosive issues that confronted Europe after the downfall of communism, nationalism proved the most intractable. When boundaries were redrawn after the upheavals of the Second World War, sizable minorities still remained within the borders of many states, as the accompanying map shows. National ambitions, suppressed or permitted only cultural expression during the decades of Communist rule, quickly resurfaced in Central and Eastern Europe, Czechoslovakia, as we have seen, divided peacefully in 1993 in response to Slovak pressures. But in Yugoslavia centuries-old national and religious tensions, kept in check under previous regimes, tore the state apart. Boundaries and names are essentially as they were from the end of the Second World War until 1990-1991. Ethnic differences in these countries made democratization and economic renewal difficult and even threatened their existence as viable states. In what was Yugoslavia, Serbs, Croats and Slovenes were inextricably intermixed, about 2 million Slavic-speaking Muslims have also long lived in Bosnia-Herzegovina and there are many Albanians, not Slavs and mostly Muslim in Kosovo and in Macedonia.

Historians debate the main causes of the breakup of Yugoslavia. Ivan Banac believes that the main reason is the historical identity of the Balkan peoples [1, p. 12]. Brown Joel drew attention to the features of Yugoslav communism [2, p. 24]. These features, according to Mike Glenn, caused the fierce war during the breakup of Yugoslavia [3, p. 44]. John Goldfarb underlines the democratic authority of the Tito regime [4, p. 78]. Ralph Darendorf is in solidarity with this view [5, p. 29]. 
The British historian Malcolm Noel points out that national problems in Kosovo [6, p. 29] and Bosnia [7, p. 44] have contributed to the destruction of the multicultural Yugoslav society. Identity wars have provoked fierce wars in the Balkans [8, p. 18]. Different Yugoslav identities hampered the emergence of communism [9, p. 87]. Todorov's Maria believes that the bloody breakup of Yugoslavia has complicated the formation of a modern European identity in the Balkans [10].

The aim of the study is to identify the nationality factor in the breakup of Yugoslavia.

\section{Material and Methods}

\section{1. Background of Balkan nationalism}

The entire large area of the Balkan Peninsula in southeastern Europe, including the once powerful medieval kingdom of Serbia, had been conquered by the Ottoman Turks in the fourteenth century and brought under Muslim rule; some parts of the area were gradually reconquered by the Habsburg. When the Ottoman Empire decayed in the nineteenth century, Serbia, after 500 years of Muslim rule, regained its status as an independent kingdom. In the late nineteenth century it found a patron in tsarist Russia, with which it shared its Eastern Orthodox Christianity. With Russian encouragement, the Serbs agitated for an enlarged South Slav or Yugoslav state for all people, speaking the Serbo-Croatian language, which is including themselves and the Croats, Slovenes and Bosnians then living in the Austro-Hungarian Empire. That agitation, because it became entangled with the pre-1914 alliance systems of the great powers, led to the First World War. The assassination at Sarajevo of the heir to the Austrian throne kindled the great conflagration in 1914 [1, p. 88].

At the collapse of the Habsburg empire in 1918, Serbia, together with likeminded South Slav nationalist, proclaimed the Kingdom of the Serbs, Croats, and Slovenes' under the Serbian monarchy, which Bosnia-Herzegovina also joined. There were ethnic, religious, and historical differences and populations were mixed throughout the new kingdom. In religion the Serbs were Eastern Orthodox Christians, the Croats and Slovenes were Roman Catholic, and in Bosnia-Herzegovina there were many Slavs, who had converted to Islam during the long Ottoman domination. But the differences, it was thought, could be submerged in the new state, which in 1929 was officially renamed Yugoslavia.

Yugoslavia was overrun and occupied by Nazi Germany during the Second World War and Croatia for a time was governed as a separate Nazi puppet state. The Yugoslavs forcefully resisted the Nazis but also fought a bitter civil war among themselves, between royalists and Communists led by Marshal Tito. The country emerged under a Communist regime, headed by Tito, who in 1946 created a federal Yugoslav republic with six component republics: Serbia, Croatia, Slovenia, Bosnia-Herzegovina, Montenegro and Macedonia, there were two autonomous provinces as well. Although himself a Croat, Tito suppressed Croatian and other separatist movements as counterrevolutionary but allowed the component republics various forms of autonomy. In Bosnia-Herzegovina he recognized the Bosnian Muslims as a distinct national group, on an equal standing with the Bosnian Serbs and Bosnian Croats. Although the Serbs and Croats together comprised over half the population of Bosnia, the Muslims, as the largest single national group, came to dominate the government [8, p. 114]. After Tito's death in 1980, separatist movements at once emerged. His successors, struggling with many other problems, including a failing economy, tried various solutions, among them a rotating federal presidency, but none worked satisfactorily. When revolutionary changes transformed Central and Eastern Europe in the late 1980s, Yugoslavia's Communist reformers loosened the regime's authoritarian grip, and the separatist pressures exploded.

\section{2. The Resurgence of Nationalism}

Here, as elsewhere in Eastern Europe and in the former Soviet Union, onetime Communist leaders, seeing power slip away because of the collapse of Communist regimes, placed themselves at the head of nationalist crusades. The Serbian one-time party leader, Slobodan Milosevic, made clear from the late 1980s his intention to rally Serbs in every one of the Yugoslav republics to his pan-Serb cause. Alarmed by Serb militancy, Croatia and Slovenia held a referendum and in 1991 proclaimed themselves independent states. They received immediate recognition from the international community, which was persuaded by Germany that prompt recognition would forestall 
Serbian aggression. Bosnia-Herzegovina, at the behest of its Muslim-dominated government but over the opposition of its Serb and Croat populations, soon followed suit. The secession of the three states and their immediate international recognition infuriated Serbia [6, p. 19].

War broke out in mid-1991 when Serbian armed forces proceeded to carve out enclaves in the many areas, where Serbian minorities lived, claiming the need to protect fellow Serbs. Serbian guerrilla forces, supported by the Serb-controlled central Yugoslav army, took up arms against Croatia and Slovenia, and seized a territory in each. After several months of fighting, in which 25000 lives were lost, a cease-fire was arranged. But the worst violence occurred when both Serbs and Croats attempted to create enclaves for themselves in Bosnia-Herzegovina. For years the mixed population, despite ethnic and religious differences, had lived peacefully side by side. In the war that ensued, which included a protracted siege of Sarajevo and other cities, terrible atrocities occurred on all sides. But it was Serbian military units and armed forces that were principally responsible for brutalizing the Muslim population and for acts of cruelty, not seen for a generation in Europe. The savage deeds, shamelessly labeled ethnic cleansing included wholesale civilian slaughter, pillage and mass rape. A shocked world cloud scarcely believes such events were occurring in the civilized Europe in the closing decade of the twentieth century. Religion and national fervor made a toxic brew [2, p. 94].

\section{Research results}

The international community could not agree on steps to confront the situation. Armed contingents of the UN were unable even to deliver humanitarian relief. The Security Council imposed economic sanctions against the rump state of Yugoslavia, consisting now of only Serbia and its historic ally, Montenegro; embargoed the shipment of arms (which mainly hurt the Muslims); and made plans for war crimes trials. But the fighting and atrocities continued. Given the historical complexity of the Balkans and the memories of earlier ferocious conflicts, neither the European powers, which might have been expected ferocious conflicts, neither the European powers, which might have been expected to take the lead, nor the United States would intervene at any early stage with any meaningful show of force. Much later, in 1994, to end the brutal siege of Sarajevo the UN, the United State, and NATO mediated a cease-fire and committed themselves to air strikes, if it were violated. For Bosnia-Herzegovina a diplomatic settlement was being negotiated whereby Croats and Muslims agreed to create a Croat-Muslim federation in what remained to them of Bosnia after the Serb, who occupied two-thirds of Bosnia and a fourth of Croatia, with every intention of retaining them. On the other hand, the Russians were now using their influence with the Serbs to bring them to the conference table. Notwithstanding the enormous differences to be resolved, there was some hope that the fighting might end, or taper off. By 1994200.000 were dead or missing, mostly in the fighting in Bosnia-Herzegovina since 1991; there were about 4.4 million displaced persons. Even with some kind of negotiated settlement, grave complications were still likely in the Balkans because of ethnic and religious tensions, ties to the outside world, and the residue of hatred and mistrust.

\section{Conclusions}

1. From 1993 to 2017 the International criminal Tribunal for the former Yugoslavia tried political and military leaders for war crime, genocide and other crimes, committed those wars. The six constituent republics that made up the Socialist Federal Republic of Yugoslavia were the Bosnia and Herzegovina, Croatia, Macedonia, Montenegro, Serbia, and Slovenia. After the breakup the Republic of Montenegro and Serbia formed a reduced federative state, officially known until 2003 as the Federal Republic of Yugoslavia. This state dissolved when Montenegro and Serbia each became independent state in 2006, and while Kosovo proclaimed its independence from Serbia in 2008.

2. An important factor in blurring multicultural identity was the revival of economic nationalism. At the heart of these political developments is economic nationalism, which is doctrine, based on predispositions and policies, which prioritize the maintenance and development of the domestic economy. An underlying assumption of economic nationalism is that people, forming a nation, enclosed within the geographical borders of a state, have a common interest, which tran- 
scends class or other social divisions within that state and takes precedence over linkages between domestic actors and foreign ones. The crucial component of economic nationalism is that national identities should determine economic outcomes. The objective of economic nationalism is to protect home industries and agricultures' from foreigners. The promotion of the interest of a nation state can be achieved by different political forms, such as one nation conservatism, autocratic politic system. The state furthers the power of domestic economic interests. The transnational nature of many modern corporations will significantly modify the promotion of national interest within a nation state. This collision is a functional and mental moor in the process of European integration of the Balkan states.

\section{References}

[1] Banac Ivan (1990). The Improbable Survivor: Yugoslavia and Its Problems 1918-1988. Beograd: Institute for international relationship.

[2] Brown, J. F. (1994). Hopes and Shadows: Eastern Europe after Communism. Durham: Duke University Press, 367. doi: http:// doi.org/10.1215/9780822379546

[3] Glenny, M. (1994). The Fall of Yugoslavia: The Third Balkan War. New York: Science Book, 257.

[4] Goldfarb, J. (1992). After the Fall: The Pursuit of Democracy in Central Europe. London: Chatem House, 288.

[5] Dahrendorf, R. (1990). Reflections on the Revolution in Europe. London: Rutledge, 163.

[6] Malcolm, N. (1994). Bosnia. A Short History. New York: New York University Press, 340.

[7] Malcolm, N. (1998). Kosovo. A Short History. London: Macmillan, 492.

[8] Ramet, P. (1993). The Destruction of Yugoslavia: Tracking the Break-Up. (1980-1992). Washington: Cartoon Press, 390.

[9] Tismaneanu, V. (1991). Eastern Europe after Communism: Reinventing Politics. Bern: Siedler Verlag.

[10] Todorova, M. (2009). Imagining the Balkans. Oxford Oxford University Press, 288. 